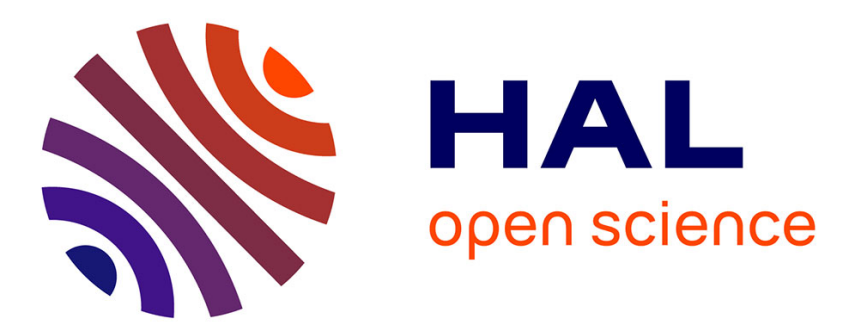

\title{
New evidence of bone tool use by Early Pleistocene hominins from Cooper's D, Bloubank Valley, South Africa
}

\author{
Raphaël Hanon, Francesco d'Errico, Lucinda Backwell, Sandrine Prat, \\ Stéphane Péan, Marylène Patou-Mathis, Christine Steininger
}

\section{To cite this version:}

Raphaël Hanon, Francesco d'Errico, Lucinda Backwell, Sandrine Prat, Stéphane Péan, et al.. New evidence of bone tool use by Early Pleistocene hominins from Cooper's D, Bloubank Valley, South Africa. Journal of Archaeological Science: Reports, 2021, 39, pp.103129. 10.1016/j.jasrep.2021.103129 . hal03385580

\author{
HAL Id: hal-03385580 \\ https://hal.science/hal-03385580
}

Submitted on 19 Oct 2021

HAL is a multi-disciplinary open access archive for the deposit and dissemination of scientific research documents, whether they are published or not. The documents may come from teaching and research institutions in France or abroad, or from public or private research centers.
L'archive ouverte pluridisciplinaire HAL, est destinée au dépôt et à la diffusion de documents scientifiques de niveau recherche, publiés ou non, émanant des établissements d'enseignement et de recherche français ou étrangers, des laboratoires publics ou privés. 
1 New evidence of bone tool use by Early Pleistocene hominins from Cooper's D, Bloubank

2 Valley, South Africa

3 Raphaël Hanon ${ }^{1,2}$, Francesco d'Errico ${ }^{3,4}$, Lucinda Backwell ${ }^{1,5}$, Sandrine Prat ${ }^{6}$, Marylène

4 Patou-Mathis ${ }^{2}$, Stéphane Péan ${ }^{2}$, Christine Steininger ${ }^{1,7}$

$5 \quad{ }^{1}$ Evolutionary Studies Institute, University of the Witwatersrand, Johannesburg, South Africa

$6 \quad{ }^{2}$ UMR 7194 (HNHP), MNHN/CNRS/UPVD, Alliance Sorbonne Université, Institut de

7 Paléontologie Humaine, 1 rue René Panhard, 75013 Paris, France

8 3 Univ. Bordeaux, UMR 5199 CNRS, De la Préhistoire à l'Actuel : Culture, Environnement, et

9 Anthropologie (PACEA), Bâtiment B18, Allée Geoffroy St Hilaire, 33615 Pessac, France.

$10{ }^{4}$ SSF Centre for Early Sapiens Behaviour (SapienCe), University of Bergen, Øysteinsgate 3, 11 Postboks 7805, 5020, Bergen, Norway.

12 Instituto Superior de Estudios Sociales (ISES-CONICET), San Lorenzo 429, San Miguel de

13 Tucumán, CP4000, Tucumán, Argentina

$14{ }^{6}$ UMR 7194 (HNHP), MNHN/CNRS/UPVD, Alliance Sorbonne Université, 17 place du

15 Trocadéro, 75116 Paris, France

$16{ }^{7}$ DST-NRF Centre of Excellence in Palaeosciences, Private Bag 3, WITS 2050,

17 Johannesburg, South Africa

18 Corresponding Author:

19 Raphaël Hanon

20 Email address: raphael.hanon@edu.mnhn.fr 
22 Bone tool-use by Early Pleistocene hominins is at the center of debates in human evolution. It

23 is especially the case in South Africa, where 102 bone tools have been described from four

24 Early Stone Age (ESA) archaeological sites, which have yielded Oldowan and possibly

25 Acheulean artefacts, as well as Paranthropus robustus and early Homo remains. Here we

26 describe a bone tool from Cooper's D. The deposit, dated between 1.4 and 1.0 Ma, has

27 yielded seven $P$. robustus remains and 50 stone artefacts. Our results highlight similarities in

28 morphology and use-wear patterns between the Cooper's D bone tool and those previously

29 identified at nearby Sterkfontein, Swartkrans, Kromdraai and Drimolen. Our findings increase

30 the number of Early Stone Age bone tools and provide further evidence of their association

31 with $P$. robustus. They suggest $P$. robustus had the cognitive capacities to develop this

32 cultural adaptation and the manipulative abilities to implement it. 
Although formal bone tools, i.e. tools entirely or almost entirely shaped with techniques specifically conceived for bone material such as scraping, grinding and grooving, are well known in the Eurasian Upper Palaeolithic and the African Later Stone Age, it is only in the last twenty years that we have begun to have information on the origin of this cultural innovation (Backwell and d'Errico, 2001; d'Errico et al., 2012, 2020). Early instances are found at Middle Stone Age sites from southern, northern, and central Africa (Brooks et al., 1995, 2006; Yellen et al., 1995; Henshilwood et al., 2001; Backwell et al., 2008, 2018; d'Errico et al., 2012, 2020; El Hajraoui and Debénath, 2012; Backwell and d'Errico, 2015). bone tools from the hominin site of Swartkrans (Brain \& Shipman 1993). Since then, evidence for the existence of an early bone tool technology at Early Stone Age (ESA) sites in South Africa has grown (Brain, 1967; Brain et al., 1988; Brain and Shipman, 1993; Backwell, 
and Backwell, 2003, 2009; Stammers et al., 2018). A growing body of data indicate that these tools mostly consist of weathered limb bone shaft fragments of medium to large size animals with a worn and polished area at the tip (Brain and Shipman, 1993; Backwell and d'Errico, 2001, 2008). According to d'Errico et al. (2001) and Backwell and d'Errico, (2001),

Swartkrans bone tools are characterized by a single rounded end with a smoothed/polished area ranging from 5 to $50 \mathrm{~mm}$ from the tip. At microscopic scale, 5-40 $\mu \mathrm{m}$ wide sub-parallel, overlapping striations oriented along the main axis of the tool cover the smoothed area. Broader striations are visible, transverse to the main axis of the bone, with a width ranging from 100 to $400 \mu \mathrm{m}$. These bones mainly derived from medial portions of long bone shafts from medium (size-class II-III) to large-size (size-class III-IV) class mammals (Brain and Shipman, 1993; Backwell and d'Errico, 2003). They have been interpreted as digging sticks used to forage for termites and plant roots, and possibly to process fruit (d'Errico and Backwell, 2009). To date, four South African sites have yielded definitive evidence of early hominin bone tool technology, namely Sterkfontein, Swartkrans, Drimolen and Kromdraai, all situated in the Cradle of Humankind UNESCO World Heritage Site, located northwest of Johannesburg (Figure 1).

Here, we provide a description of the first bone tool from the P. robustus-bearing deposit of Cooper's D. This site is dated between 1.4 and 1.0 Ma (see below), a timespan that fills the chronological gap between Swartkrans Members 2 and 3. This paper also provides descriptions of associated pseudo-tools from Cooper's D, some of which feature a similar rounded tip morphology, but lacking diagnostic traces of utilisation, and a discussion of South African ESA bone tools.

\subsection{Bone tools from Early Stone Age deposits in South Africa}


Robinson (1959) was a pioneer as he was the first to identify a bone tool from the Cradle of Humankind, from Sterkfontein Member 5 West, Acheulean Infill. In his original paper in 1959, this author proposed that Telanthropus (attributed today to Homo) was the most probable stone and bone toolmaker. The deposit has been dated by paleomagnetism to between 1.3 and 1.1 Ma, and has yielded Homo remains associated with Acheulean stone tool technology (Kuman and Clarke, 2000; Herries and Shaw, 2011). Subsequent studies provided descriptions of additional bone tools from the site of Swartkrans Members 1 to 3 (Brain et al., 1988; Brain, 1993; Brain \& Shipman 1993; Backwell and d'Errico, 2001, 2003; d'Errico and Backwell, 2003), and then from Drimolen (Backwell and d'Errico 2008), Krombraai B (Stammers et al., 2018) and possibly the Sterkfontein Name Chamber (Val and Stratford, 2015). Based on these studies, 102 bone tools have been identified at four South African early hominin sites.

The bone tool-bearing deposits cover a time span of almost one and a half million years (2.4$0.96 \mathrm{Ma}$ ). Drimolen Main Quarry (MNQ) has been recently dated c. 2.04 - 1.95 Ma (Herries et al., 2020). In the MNQ, the bone tools are associated with both Homo and Paranthropus robustus remains, as well as Oldowan stone artefacts (Keyser et al., 2000; Moggi-Cecchi et al., 2010; Stammers et al., 2018). A similar situation occurs for Swartkrans Member 1 (Brain, 1993; d'Errico and Backwell, 2003; Caruana, 2017), which is dated between 2.4 and $1.8 \mathrm{Ma}$ (Pickering et al., 2019). In Member 2 of Swartkrans, dated c. 1.4 Ma, an Acheulean stone tool industry is found associated with bone tools and both Homo and P. robustus remains (Brain, 1993; d'Errico and Backwell, 2003; Kuman, 2007; Balter et al., 2008). The largest collection of bone tools was found in Swartkrans Member 3, which is dated c. $0.96 \mathrm{Ma}$, associated with an Acheulean Industry and only P. robustus remains (Brain, 1993; d'Errico and Backwell, 2003; Kuman, 2007; Gibbon et al., 2014). Two bone tools have been described from the 
104 Kromdraai B site, which has yielded only two stone tools and P. robustus remains (Kuman,

105 2007; Braga et al., 2017; Stammers et al., 2018). The age of this deposit is unresolved, but it 106 is thought to be $>2.2 \mathrm{Ma}$ (Bruxelles et al., 2017). Finally, one bone tool is reported from the 107 newly excavated area of the Sterkfontein Name Chamber (Val and Stratford, 2015), but we

108 still lack photographic evidence supporting its identification, and the age of the deposit is

109 unclear; a mixture of Members 4 (2.95-1.95 Ma; Pickering and Kramers, 2010) and 5 East

110 Oldowan (2.18 $\pm 0.21 \mathrm{Ma}$; Granger et al., 2015).

\subsection{Cooper's D site}

112 Cooper's Cave is located in the UNESCO Sterkfontein, Swartkrans, Kromdraai and Environs

113 World Heritage Site in South Africa, at $1.5 \mathrm{~km}$ northeast of Sterkfontein, $1 \mathrm{~km}$ southwest of

114 Kromdraai, and $45 \mathrm{~km}$ northwest of Johannesburg (Figure 1) (Berger et al., 2003; de Ruiter et

115 al., 2009). These cave deposits occur on dolomite of the Monte Cristo Formation (Malmani

116 Subgroup, Transvaal Supergroup) and yield abundant fossil assemblages in both calcified and

117 decalcified breccias (Berger et al., 2003; Steininger et al., 2008; de Ruiter et al., 2009).

118 Excavations at Cooper's between 2001 and 2009, were conducted in decalcified sediments,

119 which has preserved an abundant fossil assemblage of large and small vertebrates (n

$120>50,000)$, stone tools $(n=49)$, and seven hominin remains, six of them attributed to

121 Paranthropus robustus (Berger et al., 2003; Steininger et al., 2008; de Ruiter et al., 2009;

122 Sutton et al., 2017). The first radiometric uranium-lead (U-Pb) dates estimated the age of the

123 basal speleothem to be $1.526 \pm 0.088 \mathrm{Ma}$ (de Ruiter et al., 2009). A flowstone layer situated in

124 the middle of the deposit was dated to $c$. 1.4 Ma. A more recent study based on the resampling

125 of the basal speleothem for U-Pb dating gives an age of the basal speleothem to be

126 1.375 $\pm 0.113 \mathrm{Ma}$ (Pickering et al., 2019). A minimum age of $1.0 \mathrm{Ma}$ for the deposit is 
proposed by Hanon (2019), based on biochronological data from the large mammal

128 assemblage. Thus, we assume that the Cooper's D material from decalcified sediments accumulated between $c .1 .4$ and 1.0 Ma.

Two previous taphonomic studies were conducted on large mammal sub-assemblages at

131 Cooper's D (de Ruiter et al., 2009; Val et al., 2014). The first one focused on a sub-sample of

132 the large mammal assemblage, and suggested that a hyaenid - particularly the brown hyaena

133 (Parahyaena brunnea) - was the main accumulating agent of the faunal deposit (de Ruiter et

134 al., 2009). The second study relied on the large-bodied primate assemblage to suggest that

135 both leopards and hyaenas were the most probable accumulating agents (Val et al., 2014).

136 These two studies did not report any bone surface modifications consistent with damage

137 produced by hominins through carcass exploitation or the use of bone tools.

138 The first extensive taphonomic study of the Cooper's D large mammal assemblage, conducted

139 by one of us (Hanon, 2019), led to the identification of butchery marks and potential bone

140 tools that are the subject of the present study.

\section{Materials and methods}

142 Between 2017 and 2018, we undertook a taphonomic study of the entire large mammal faunal

143 assemblage, composed of 21,193 specimens housed at the Evolutionary Studies Institute,

144 University of Witwatersrand, Johannesburg. For our anatomical and taxonomic

145 identifications, we used the modern osteological collection housed in the same institution. We

146 also compared Cooper's material to the modern collections and fossil assemblages from

147 Sterkfontein, Swartkrans and Kromdraai, housed at the Ditsong National Museum of Natural

148 History, Tswane (formerly Pretoria). Potential bone tools identified during the taphonomic

149 study of the Cooper's D assemblage were macro- and microscopically compared with 
previously identified bone tools from Swartkrans housed at the Ditsong National Museum of

151 Natural History, and those published from Sterkfontein, Drimolen and Kromdraai.

152 All specimens from the large Cooper's D faunal collection were observed using an Olympus

153 SZ51 binocular microscope (10-40x magnification). We recorded the following bone

154 modifications: fracture pattern, weathering stage, cortical preservation state, abrasion and

155 polish, manganese coating, decalcification, concretion, compaction, carnivore and rodent

156 tooth marks, trampling and butchery marks, microbial damage and insect modification. These

157 identifications were made based on criteria developed by several authors (e.g. Behrensmeyer,

158 1978; Binford, 1978; Brain, 1980, 1981; Maguire et al., 1980; Potts and Shipman, 1981;

159 Shipman and Rose, 1983, 1983; Behrensmeyer et al., 1986; Hill, 1987; Blumenschine, 1988;

160 Blumenschine and Selvaggio, 1988; Olsen and Shipman, 1988; Fiorillo, 1989; Cruz-Uribe,

161 1991; Villa and Mahieu, 1991; Lyman, 1994; Blumenschine et al., 1996; Patou-Mathis, 1997;

162 Kaiser, 2000; Pickering, 2002; Domínguez-Rodrigo et al., 2009, 2010; Kuhn et al., 2010;

163 Backwell et al., 2012; Fourvel, 2012; Bountalis and Kuhn, 2014; Huchet, 2014; Parkinson,

164 2016). The results of this comprehensive taphonomic analysis will be published elsewhere

165 (Hanon et al., in prep.). This led us to identify 12 possible bone tools featuring morphological

166 characters matching, to some extent, those published by Backwell and d'Errico $(2001,2004)$

167 and Pante et al. (2020). These pieces were photographed with a Dino-Lite AD7013MTL

168 digital microscope (20-100x magnification) and an Olympus SZX 16 multifocal microscope

169 coupled to a digital camera (7-115x magnification).

170 Selected areas of these specimens were moulded with a silicone dental elastomer (Coltène

171 President light body) and analysed with the Tescan Vega 2 LSU scanning electron microscope

172 (SEM) housed at the Muséum national d'Histoire naturelle electron microscopy and

173 microanalysis technical platform, Paris. The resin replicas were not metal coated, and all the 
174 images were taken using $15.00 \mathrm{kV}, 25 \mathrm{~Pa}$ and a view field ranging from 15 to $1 \mathrm{~mm}$ with a

175 LVSTD detector. Transparent replicas were made with the MA2+ resin (PRESI, France).

176 These casts were examined in reflected and transmitted light using a motorized Leica Z6

177 APOA microscope equipped with a DFC420 digital camera and the Leica Application Suite

178 (LAS) software, including the multifocal module (4-40x magnification). This microscope

179 used digital images acquired at variable heights and combined them to obtain a single

180 composite image with an extensive depth of field. As a reference we used descriptions and

181 images of early hominin bone tools from South Africa provided by the literature, and

182 experimental counterparts used in tasks such as digging in different sedimentary

183 environments, digging for termites, plant roots, and fruit processing (Backwell and d'Errico,

184 2001, 2004, 2008; d'Errico and Backwell, 2003, 2009).

186 Examination of the 21,193 large mammal bone specimens resulted in the selection of 12

187 potential bone tools (Table 1). Two bones were identified as fragments of bovid metapodials.

188 The rest of the specimens are unidentifiable to taxonomic level and skeletal element. Most of

189 the bones belong to size class I and II mammals $(n=9 / 12$, Table 2$)$. This small assemblage is

190 composed of well-preserved specimens with no sign of abrasion $(n=8 / 12)$, as well as very

191 abraded bone fragments $(n=4 / 12$, Table 3). No modification by biological agents was

192 identified. Morphometric data on each specimen are provided in Table 1.

193 The two limb shaft fragments CD.9977 and CD.3046C (Figure 2) have bevelled edges that

194 appear to be the result of fresh bone fracture. These specimens are characterized by the

195 presence of contiguous micro flake scars along their sides. The sharpness of the edges,

196 however, indicates the flake scars may result from post-depositional processes such as 
trampling or sediment compression. Six other specimens (CD.343, CD.3528, CD.7900,

198 CD.3529, CD.1649, CD.15631) mimic the general morphology of bone tools found at early

199 Pleistocene hominin sites (Figure 3). However, at microscopic scale, we were not able to

200 identify the diagnostic use-wear pattern associated with the fossil tools, and the smoothing

201 present on them generally extends to the entire bone surface, which is consistent with the

202 action of a natural agent such as water abrasion.

CD.3538 (Figure 3d) is a limb bone shaft fragment with a morphology similar to that of early

204 Pleistocene hominin bone tools. However, no typical use-wear pattern is visible at a

205 microscopic scale, and the preservation of the periosteal surface is more consistent with that

206 resulting from a digestion process. For these reasons we identified this specimen as modified

207 by a carnivore.

208 CD.6978A (Figure 4a) is a fragment of a small bovid metapodial (size class II). One end is

209 bevelled, while the other shows a transverse fracture on dry bone. A crack parallel to the main

210 axis of the bone structure is visible on its periosteal surface. We attribute this crack to a

211 potential post-depositional process rather than to weathering, since no other evidence of

212 exposure is observable on the bone. The specimen has a manganese coating. The general

213 morphology is very similar to that of bone tools identified at Swartkrans, Drimolen and

214 Kromdraai, but we did not observe the use-wear pattern found on the bone tools from these

215 sites (Figure 4b).

216 CD.1293 (Figure 4c) is an indeterminate long bone shaft fragment attributed to a size class II

217 mammal. The piece is bevelled with a slightly smoothed end. Dry breakage is observed at the

218 opposite end as well as stage 1 weathering. However, the absence of microstriations and 
polish restricted to the area of the tip does not permit us to identify this specimen as a bone tool (Figure 4d).

221 Only one specimen can be confidently identified as a bone tool. CD.7895 (Figures 5-7) is a

222 fragment of an indeterminate long bone characterized by a rounded end. The other end has a

223 dry bone fracture. The general morphology of the fragment may correspond to a bovid 224 metapodial. The piece belongs to an animal of size class 2 . The use-wear pattern is visible 225 from the tip for $28.9 \mathrm{~mm}$ along the edge, medullary and periosteal surfaces of the bone 226 (Figures 5-7). The microstriae are clearly visible on both multifocal and SEM photographs 227 (Figures 5-7). They are mostly longitudinal or oblique to the main axis of the long bone and 228 appear, as on well-preserved specimens from Swartkrans and Drimolen, to result from 229 abrasion by individual particles, each following a slightly different trajectory and marking 230 successively the bone surface. Microstriation widths are highly variable, ranging from 25 to $231300 \mu \mathrm{m}$. However, very few striations with a width $>45 \mu \mathrm{m}$ can be observed. Most of them 232 are curved and subparallel to the main axis of the bone. Longitudinal thin cracks indicate the 233 bone was at a weathering stage 1 when it was used as a tool.

\section{Discussion}

235 During our taphonomic investigation of the large mammal collection from Cooper's D, we 236 were able to identify 12 specimens as bone tools or pseudo-tools. However, after close 237 microscopic examination, only one specimen can be securely identified as a bone tool. The 238 remaining 11 pieces are interpreted as pseudo-tools produced by non-human post-depositional 239 processes, or tools so heavily affected by natural processes that their identification as 240 implements is impossible. 
The CD.7895 bone tool from Cooper's D bears features (i.e. rounded and strongly polished

242 end associated with longitudinal or oblique microstriae between 25 to $300 \mu \mathrm{m}$ wide) identical

243 to those identified on bone tools from the Sterkfontein, Swartkrans, Drimolen and Kromdraai

244 sites (Backwell and d'Errico, 2008; d'Errico and Backwell, 2009; Stammers et al., 2018). At

245 Cooper's D, the faunal material is dominated by small to medium size class mammals

246 (Hanon, 2019) and the only bone tool specimen is attributed to a size-class II mammal. At

247 Sterkfontein and Swartkrans, mammal size class II-III and III-IV dominate the bone tool

248 assemblage, while at Drimolen, the size class II-III is dominant and the mammals over or

249 under this size class are underrepresented. The bone tool from Cooper's D has been made on a

250 bovid metapodial, which is consistent with the trend observed at Swartkrans and Drimolen,

251 where the majority of the bone tools were obtained from long bone shaft fragments (Backwell

252 and d'Errico, 2003, 2008). Unlike these assemblages, we found no bone tools made from

253 horncores, mandibles or ribs. This is not surprising, however, if one considers that they occur

254 at the two sites in very low proportions.

255 The wear-pattern observed on the tip of the CD.7895 specimen from Cooper's D is very

256 similar to that recorded on bone tools from Sterkfontein, Swartkrans and Drimolen (Backwell

257 and d'Errico, 2008). Originally, these bone tools were interpreted as digging implements to

258 dig up tubers (Brain and Shipman, 1993). Subsequent quantitative study and comparison

259 between archaeological and experimental specimens lead some authors to suggest that these

260 bone tools were used for termite foraging (Backwell and d'Errico, 2001, 2008; d'Errico et al.,

261 2001). Subsequently, more detailed analysis of the bone surface texture indicated that even

262 though termite foraging is the most likely task for the Drimolen bone tools, other foraging

263 activities such as fruit processing and extraction of tubers could also be possible (d'Errico and

264 Backwell, 2009). It is difficult, at this stage, to assess the function of the bone tool from 
265 Cooper's D, but given the orientation and fine width of the striations we propose termite 266 foraging as most likely.

267 Bone tools from Swartkrans Member $1(n=32)$, which is dated between 2.249 \pm 0.077 $2681.706 \pm 0.069 \mathrm{Ma}$, is associated with the Oldowan stone tool industry, P. robustus and $H$. cf. 269 erectus (Backwell and d'Errico, 2001, 2003; d'Errico and Backwell, 2003; Caruana, 2017; 270 Pickering et al., 2019). According to Herries et al. (2020) the depositional age of Swartkrans 271 Member 1 remains uncertain, and based on ESR dates and faunal evidence could have 272 occurred somewhere between 2.4 and 1.8 Ma, most likely 1.8 Ma. Based on this assertion, 273 Drimolen MNQ, recently dated between 2.04 - 1.95 Ma, could represent the oldest 274 occurrence in southern Africa of bone tools $(\mathrm{n}=14)$, stone tools, Homo and Paranthropus 275 (Herries et al., 2020). The bone tools apparently disappear around $0.96 \mathrm{Ma}$, with the last 276 occurrence in Swartkrans Member 3 ( $n=41$; Brain, 1993; Backwell and d'Errico, 2003). This 277 implies that bone tools are known in South Africa from at least 2.4 to 0.96 Ma. During this 278 time, five sites have yielded definitive evidence of bone tool technology (Table 4). The 279 Cooper's D assemblage fills the chronological gap between Swartkrans Members 2 and 3. At 280 Cooper's D, P. robustus is the only hominin identified (Steininger et al., 2008; de Ruiter et 281 al., 2009). According to Sutton et al. (2017), there are 49 stone artefacts from Cooper's D, but 282 this small assemblage does not permit allocating them to a specific industry. Although two 283 bone tools are reported from the Kromdraai B deposit (Stammers et al., 2018), there is an 284 absence of clear radiometric dates. A second bone tool has been reported from Sterkfontein, 285 from the Name Chamber (Val and Stratford, 2015), and while a detailed study of this 286 specimen is lacking, it confirms a bone tool technology at this site.

287 We agree with Stammers et al. (2018) that an overall study of these sites shows no clear 288 pattern of associations with bone tools, not with hominins or stone tool industry. Bone tools 
are associated with Oldowan as well as Acheulian stone tool industries in deposits containing

290 P. robustus and early Homo remains (Table 4). Some authors have suggested a link between

291 the presence of $P$. robustus and the early bone tools (Brain, 1993; Backwell and d'Errico,

292 2003, 2008). Indeed, the largest collection of ESA bone tools has been discovered in

293 Swartkrans Member 3, which is rich in Paranthropus remains (Brain, 1993). Drimolen MNQ

294 has also yielded a large number of $P$. robustus remains associated with a collection of bone

295 tools (Backwell and d'Errico, 2008). Finally, South African bone tools disappear after 0.96

296 Ma in Swartkrans Member 3, as is the case for both P. robustus and early Homo. We can

297 assume that the most parsimonious hypothesis is that Paranthropus may have been the user of

298 the bone tools, but the presence of Homo complicates the picture (Backwell and d'Errico,

299 2008; Stammers et al., 2018; Herries et al., 2020).

301 In this study we identify and describe the first bone tool from the Cooper's D faunal

302 assemblage. The general morphology and use-wear pattern observed at the tip of the Cooper's

303 D bone tool are very similar to that observed on bone tools from Sterkfontein, Swartkrans and

304 Drimolen. It has been shown that these tools were probably used to forage for termites and 305 plant roots and to process fruits. Based on the longitudinal orientation of the fine striations at

306 the tip of the specimen we tentatively propose that it was used in termite foraging, but wish to

307 investigate further this issue in the future. The fact that $P$. robustus is the only hominin

308 identified at Cooper's D supports the hypothesis that $P$. robustus probably used the bone tool

309 (Brain, 1993; Backwell and d'Errico, 2001, 2003). 
311 We would like to thank Sylvain Pont who helped us visualizing specimens with the SEM at

312 the MNHN, and Eric Pubert for producing resin casts. We thank Bernhard Zipfel from the

313 University of the Witwatersrand, and Stephany Potze, Mirriam Tawane, Heidi Fourie and

314 Lazarus Kgasi from the Ditsong Museum, Tswane (Pretoria), for access to collections. CMS

315 acknowledges the funding contribution of the Centre of Excellence in Palaeosciences (CoE-

316 Palaeo) and the Palaeontological Scientific Trust (PAST). RH acknowledges the ATM

317 MNHN project "Paranthropus Diet. Régime alimentaire et comportement de subsistance des

318 Paranthropes sud-africains", directed by S. Prat, the UMR 7194/MNHN, the Agence

319 Nationale de la Recherche (ANR, France): project HOMTECH, ANR-17-CE27-0005,

320 directed by S. Prat, for funding and logistical support. FdE acknowledges support from the

321 Research Council of Norway through its Centre's of Excellence funding scheme (SFF Centre

322 for Early Sapiens Behaviour - SapienCE- project number 262618), the Talents programme of 323 the University of Bordeaux Initiative d'Excellence, and the LaScArBx (ANR-10-LABX-52).

324 LB is grateful for a DSI-NRF Centre of Excellence in Palaeosciences grant (CEOOP2020-1).

325 References

326 Backwell, L.R., d'Errico, F., 2001. Evidence of termite foraging by Swartkrans early hominids. Proceedings of the National Academy of Sciences. 98, 13581363.Backwell, L., Bradfield, J., Carlson, K.J., Jashashvili, T., Wadley, L., d’Errico, F., 2018. The antiquity of bow-and-arrow technology: evidence from Middle Stone Age layers at Sibudu Cave. Antiquity. 92, 289-303.

331 Backwell, L., d'Errico, F., 2005. The origin of bone tool technology and the identification of early hominid cultural traditions. In: d'Errico, F., Backwell, L. (Eds.), From Tools to 

Johannesburg, pp. 238-275.

335 Backwell, L., d'Errico, F., 2008. Early hominid bone tools from Drimolen, South Africa. Journal of Archaeological Science. 35, 2880-2894.

Backwell, L., d’Errico, F., 2015. Osseous Projectile Weaponry from Early to Late Middle Stone Age Africa. In: Langley, M.C. (Ed.), Osseous Projectile Weaponry, Vertebrate Paleobiology and Paleoanthropology. Springer Netherlands, Dordrecht, pp. 15-29.

Backwell, L., d'Errico, F., Wadley, L., 2008. Middle Stone Age bone tools from the Howiesons Poort layers, Sibudu Cave, South Africa. Journal of Archaeological Science. $35,1566-1580$.

Backwell, L.R., 2000. A critical assessment of southern African 'early hominid bone tools.' University of the Witwatersrand, Johannesburg.

Backwell, L.R., d'Errico, F., 2001. Evidence of termite foraging by Swartkrans early hominids. Proceedings of the National Academy of Sciences. 98, 1358-1363.

347 Backwell, L.R., d'Errico, F., 2003. Additional evidence on the early hominid bone tools from Swartkrans with reference to spatial distribution of lithic and organic artefacts. South African Journal of Science. 99, 259-267.

Backwell, L.R., d'Errico, F., 2004. The first use of bone tools: a reappraisal of the evidence from Olduvai Gorge, Tanzania. 64. 
Backwell, L.R., Parkinson, A.H., Roberts, E.M., d'Errico, F., Huchet, J.-B., 2012. Criteria for identifying bone modification by termites in the fossil record. Palaeogeography, Palaeoclimatology, Palaeoecology. 337-338, 72-87.

Balter, V., Blichert-Toft, J., Braga, J., Telouk, P., Thackeray, F., Albarède, F., 2008. U-Pb dating of fossil enamel from the Swartkrans Pleistocene hominid site, South Africa. Earth and Planetary Science Letters. 267, 236-246.

Behrensmeyer, A.K., 1978. Taphonomic and Ecologic Information from Bone Weathering. Paleobiology. 4, 150-162.

Behrensmeyer, A.K., Gordon, K.D., Yanagi, G.T., 1986. Trampling as a cause of bone surface dama and pseudo-cutmarks. Nature. 319, 768-771.

Berger, L.R., de Ruiter, D.J., Steininger, C.M., Hancox, J., 2003. Preliminary results of excavations at the newly investigated Coopers D deposit, Gauteng, South Africa. South African Journal of Science. 99, 276-278.

Binford, L.R., 1978. Nunamiut Ethnoarchaeology, Academic Press. ed. New York.

Blumenschine, R.J., 1988. An experimental model of the timing of hominid and carnivore influence on archaeological bone assemblages. Journal of Archaeological Science. 15, $483-502$.

Blumenschine, R.J., Marean, C.W., Capaldo, S.D., 1996. Blind Tests of Inter-analyst Correspondence and Accuracy in the Identification of Cut Marks, Percussion Marks, and Carnivore Tooth Marks on Bone Surfaces. Journal of Archaeological Science. 23, 493-507. 
Blumenschine, R.J., Selvaggio, M.M., 1988. Percussion marks on bone surfaces as a new diagnostic of hominid behaviour. Nature. 333, 763-765.

Bountalis, A.C., Kuhn, B.F., 2014. Cave Usage by Multiple Taphonomic Agents: Issues towards Interpreting the Fossil Bearing Cave Deposits in South Africa. American Journal of Zoological Research. 2, 55-61.

Braga, J., Thackeray, J.F., Bruxelles, L., Dumoncel, J., Fourvel, J.-B., 2017. Stretching the time span of hominin evolution at Kromdraai (Gauteng, South Africa): Recent discoveries. Comptes Rendus Palevol. 16, 58-70.

Brain, C.K., 1967. Bone weathering and the problem of bone pseudo-tools. South African Journal of Science. 63, 97-99.

Brain, C.K., 1980. Some criteria for the recognition of bone-collecting agencies in African caves. In: Fossils in the Making: Vertebrate Taphonomy and Paleoecology. Behrensmeyer, A. K. and Hill, A. P., Chicago, pp. 107-130.

Brain, C.K., 1981. The Hunters or the Hunted? An Introduction to African Cave Taphonomy. University of Chicago Press, Chicago.

Brain, C.K., 1993. Swartkrans. A Cave's Chronicle of Early Man. Transvaal Museum, Pretoria.

Brain, C.K., Churcher, C.S., Clark, J.D., Grine, F.E., Shipman, P., Susman, R.L., Turner, A., Watson', V., 1988. New evidence of early hominids, their culture and environment from the Swartkrans cave, South Africa. South African Journal of Science. 84, 828835. 
Brain, C.K., Shipman, P., 1993. The Swartkrans bone tools. In: Brain, C.K. (Ed.), Swartkrans: A Cave's Chronicle of Early Man. Transvaal Museum Monograph, Pretoria, pp. 195215.

Brooks, A., Helgren, D., Cramer, J., Franklin, A., Hornyak, W., Keating, J., Klein, R., Rink, W., Schwarcz, H., Smith, J., et, al., 1995. Dating and context of three middle stone age sites with bone points in the Upper Semliki Valley, Zaire. Science. 268, 548-553.

Brooks, A.S., Nevell, L., Yellen, J.E., Hartman, G., 2006. Projectile technologies of the MSA: implications for modern human origins. In: Hovers, E., Kuhn, S.L. (Eds.), Transitions before the Transition: Evolution and Stability in the Middle Palaeolithic and Middle Stone Age. Springer, New York, pp. 233-255.

Bruxelles, L., Maire, R., Couzens, R., Thackeray, J.F., Braga, J., 2017. A revised stratigraphy of Kromdraai. In: Kromdraai, a Birthplace of Paranthropus in the Cradle of Humankind. Sun Media Metro, Johannesburg, pp. 31-48.

Caruana, M.V., 2017. Lithic Production Strategies in the Oldowan Assemblages from Sterkfontein Member 5 and Swartkrans Member 1, Gauteng Province, South Africa. Journal of African Archaeology. 15, 1-19.

Cruz-Uribe, K., 1991. Distinguishing Hyena from Hominid Bone Accumulations. Journal of Field Archaeology. 18, 467.

d'Errico, F., Backwell, L., 2009. Assessing the function of early hominin bone tools. Journal of Archaeological Science. 36, 1764-1773. 
414 d'Errico, F., Backwell, L.R., 2003. Possible evidence of bone tool shaping by Swartkrans early hominids. Journal of Archaeological Science. 30, 1559-1576.

416 d'Errico, F., Backwell, L.R., Berger, L.R., 2001. Bone tool use in termite foraging by early hominids and its impact on our understanding of early hominid behaviour. South African Journal of Science. 97, 71-75.

d'Errico, F., Backwell, L.R., Wadley, L., 2012. Identifying regional variability in Middle Stone Age bone technology: The case of Sibudu Cave. Journal of Archaeological Science. 39, 2479-2495.

d'Errico, F., Pitarch Martí, A., Shipton, C., Le Vraux, E., Ndiema, E., Goldstein, S., Petraglia, M.D., Boivin, N., 2020. Trajectories of cultural innovation from the Middle to Later Stone Age in Eastern Africa: Personal ornaments, bone artifacts, and ocher from Panga ya Saidi, Kenya. Journal of Human Evolution. 141, 102737.

Dart, R.A., 1957. The osteodontokeratic culture of Australopithecus prometheus. Transvaal Museum Memoirs. 1-105.

de Ruiter, D.J., Pickering, R., Steininger, C.M., Kramers, J.D., Hancox, P.J., Churchill, S.E., Berger, L.R., Backwell, L., 2009. New Australopithecus robustus fossils and associated U-Pb dates from Cooper's Cave (Gauteng, South Africa). Journal of Human Evolution. 56, 497-513.

Domínguez-Rodrigo, M., de Juana, S., Galán, A.B., Rodríguez, M., 2009. A new protocol to differentiate trampling marks from butchery cut marks. Journal of Archaeological Science. 36, 2643-2654. 
Domínguez-Rodrigo, M., Pickering, T.R., Bunn, H.T., 2010. Configurational approach to identifying the earliest hominin butchers. Proceedings of the National Academy of Sciences. 107, 20929-20934.

Doyon, L., Zhanyang, L., Hua, W., Geis, L., d'Errico, F., 2020. A 115,000-year-old expedient bone technology at Lingjing, Henan, China (preprint). SocArXiv.

El Hajraoui, A.M., Debénath, A., 2012. El Mnasra - Chapitre XXIV. L'industrie osseuse. In: El Hajraoui, A.M., Nespoulet, R., Debénath, A., Dibble, H. (Eds.), Préhistoire de La Région de Rabat-Témara. Villes et Sites d'archéologie Marocaine, Royaume Du Maroc. Ministère de la Culture et Institut Narional des Sciences de l'Archéologie et du Patrimoine, Rabat, pp. 179-188.

Fiorillo, A.R., 1989. An experimental study of trampling. In: Bonnichsen, R., and Sorg, M. H., (Eds.), Bone Modification. University of Maine, pp. 61-98.

Fourvel, J.-B., 2012. Hyénidés modernes et fossiles d'Europe et d'Afrique : taphonomie comparée de leurs assemblages osseux. Université de Toulouse Le Mirail, Toulouse.

Gibbon, R.J., Pickering, T.R., Sutton, M.B., Heaton, J.L., Kuman, K., Clarke, R.J., Brain, C.K., Granger, D.E., 2014. Cosmogenic nuclide burial dating of hominin-bearing Pleistocene cave deposits at Swartkrans, South Africa. Quaternary Geochronology. 24, $10-15$.

Granger, D.E., Gibbon, R.J., Kuman, K., Clarke, R.J., Bruxelles, L., Caffee, M.W., 2015. New cosmogenic burial ages for Sterkfontein Member 2 Australopithecus and Member 5 Oldowan. Nature. 522, 85-88. 
Hanon, R., 2019. Comportements de subsistance des hominines du Pléistocène inférieur d'Afrique du Sud : analyse archéozoologique du site de Cooper's D (Bloubank Valley). Muséum National d'Hisazeazeoire Naturelle, Paris.

Henshilwood, C.S., D’errico, F., Marean, C.W., Milo, R.G., Yates, R., 2001. An early bone tool industry from the Middle Stone Age at Blombos Cave, South Africa: implications for the origins of modern human behaviour, symbolism and language. Journal of Human Evolution. 41, 631-678.

Herries, A.I.R., Curnoe, D., Adams, J.W., 2009. A multi-disciplinary seriation of early Homo and Paranthropus bearing palaeocaves in southern Africa. Quaternary International. 202, 14-28.

Herries, A.I.R., Hopley, P.J., Adams, J.W., Curnoe, D., Maslin, M.A., 2010. Letter to the editor: Geochronology and palaeoenvironments of Southern African hominin-bearing localities-A reply to Wrangham et al., 2009. "Shallow-water habitats as sources of fallback foods for hominins.” American Journal of Physical Anthropology. 143, 640646.

Herries, A.I.R., Martin, J.M., Leece, A.B., Adams, J.W., Boschian, G., Joannes-Boyau, R., Edwards, T.R., Mallett, T., Massey, J., Murszewski, A., Neubauer, S., Pickering, R., Strait, D.S., Armstrong, B.J., Baker, S., Caruana, M.V., Denham, T., Hellstrom, J., Moggi-Cecchi, J., Mokobane, S., Penzo-Kajewski, P., Rovinsky, D.S., Schwartz, G.T., Stammers, R.C., Wilson, C., Woodhead, J., Menter, C., 2020. Contemporaneity of Australopithecus, Paranthropus, and early Homo erectus in South Africa. Science. 368, eaaw7293. 
Herries, A.I.R., Shaw, J., 2011. Palaeomagnetic analysis of the Sterkfontein palaeocave deposits: Implications for the age of the hominin fossils and stone tool industries. Journal of Human Evolution. 60, 523-539.

Hill, A., 1987. Damage to some fossil bones from Laetoli. In: Leakey, M. D., and Harris, J. M., (Eds.), Laetoli. A Pliocene Site in Northern Tanzania. Oxford, pp. 543-544.

Huchet, J.-B., 2014. Approche ichnologique et taphonomique des altérations ostéolytiques dues aux insectes en contexte archéologique. In: Denys, C., and Patou-Mathis, M., (Eds.), Manuel de Taphonomie, Collection “Archéologiques.” Errance, Muséum National d'Histoire Naturelle and CNRS, Paris, pp. 185-207.

Kaiser, T.M., 2000. Proposed Fossil Insect Modification to Fossil Mammalian Bone from Plio-Pleistocene Hominid-Bearing Deposits of Laetoli (Northern Tanzania). Annals of the Entomological Society of America. 93, 693-700.

Keyser, A.W., Menter, C.G., Moggi-Cecchi, J., Pickering, T.R., Berger, L.R., 2000. Drimolen: a new hominid-bearing site in Gauteng, South Africa. South African Journal of Science. 96, 193-197.

Kuhn, B.F., Berger, L.R., Skinner, J.D., 2010. Examining criteria for identifying and differentiating fossil faunal assemblages accumulated by hyenas and hominins using extant hyenid accumulations. International Journal of Osteoarchaeology. 15-35.

Kuman, K., 2007. The earlier Stone Age in South Africa: site context and the influence of cave studies. In: Pickering, T. R., Schick, K., and Toth, N., (Eds.), Breathing Life Into Fossils: Taphonomic Studies in Honor of C. K. (Bob) Brain. Gosport, pp. 181-198. 
Kuman, K., Clarke, R.J., 2000. Stratigraphy, artefact industries and hominid associations for Sterkfontein, Member 5. Journal of Human Evolution. 38, 827-847.

Lyman, R.L., 1994. Vertebrate Taphonomy, Cambridge University Press. ed, Cambridge manuals in archaeology. Cambridge.

Maguire, J.M., Pemberton, D., Collett, M.H., 1980. The Makapansgat limeworks gray breccia: hominids, hyaenas, hystricids or hill wash. Palaeontologia africana. 23, 7598.

Moggi-Cecchi, J., Menter, C., Boccone, S., Keyser, A., 2010. Early hominin dental remains from the Plio-Pleistocene site of Drimolen, South Africa. Journal of Human Evolution. $58,374-405$.

Olsen, S.L., Shipman, P., 1988. Surface modification on bone: Trampling versus butchery. Journal of Archaeological Science. 15, 535-553.

Pante, M., Torre, I. de la, d'Errico, F., Njau, J., Blumenschine, R., 2020. Bone tools from Beds II-IV, Olduvai Gorge, Tanzania, and implications for the origins and evolution of bone technology. Journal of Human Evolution. 148, 102885.

Parkinson, A.H., 2016. Traces of Insect Activity at Cooper's D Fossil Site (Cradle of Humankind, South Africa). Ichnos. 23, 322-339.

Patou-Mathis, M., 1997. Les marques de boucherie au Paléolithique. Revue Médical Vétérinaire. 148, 959-968.

Pickering, R., Herries, A.I.R., Woodhead, J.D., Hellstrom, J.C., Green, H.E., Paul, B., Ritzman, T., Strait, D.S., Schoville, B.J., Hancox, P.J., 2019. U-Pb-dated flowstones 

229.

522 Pickering, R., Kramers, J.D., 2010. Re-appraisal of the stratigraphy and determination of new $\mathrm{U}-\mathrm{Pb}$ dates for the Sterkfontein hominin site, South Africa. Journal of Human Evolution. 59, 70-86.

Pickering, T.R., 2002. Reconsideration of criteria for differentiating faunal assemblages accumulated by hyenas and hominids. International Journal of Osteoarchaeology. 12, $127-141$

Porraz, G., E., P.J., Schmidt, P., Gérald, B., Jean-Philippe, B., Laure, D., Marina, I., Miller, C.E., Schmid, V.C., Chantal, T., Aurore, V., Christine, V., Pierre-Jean, T., 2020. Experimentation preceding innovation in a MIS5 Pre-Still Bay layer from Diepkloof Rock Shelter (South Africa): emerging technologies and symbols (preprint). EcoEvoRxiv.

Potts, R., Shipman, P., 1981. Cutmarks made by stone tools on bones from Olduvai Gorge, Tanzania. Nature. 291, 577-580.

Robinson, J.T., 1959. A Bone Implement from Sterkfontein. Nature. 184, 583-585.

Shipman, P., Rose, J., 1983. Early hominid hunting, butchering, and carcass-processing behaviors: Approaches to the fossil record. Journal of Anthropological Archaeology. 2, 57-98. 
Stammers, R.C., Caruana, M.V., Herries, A.I.R., 2018. The first bone tools from Kromdraai and stone tools from Drimolen, and the place of bone tools in the South African Earlier Stone Age. Quaternary International. 495, 87-101.

Steininger, C., Berger, L.R., Kuhn, B.F., 2008. A partial skull of Paranthropus robustus from Cooper's Cave, South Africa. South African Journal of Science. 104, 143-146.

Sutton, M.B., Kuman, K., Steininger, C., 2017. Early Pleistocene stone artefacts from Cooper's cave, South Africa. South African Archaeological Bulletin. 72, 156-161.

Val, A., Stratford, D.J., 2015. The macrovertebrate fossil assemblage from the Name Chamber, Sterkfontein: taxonomy, taphonomy and implications for site formation processes. Palaeontologia Africana. 50, 49-58.

Val, A., Taru, P., Steininger, C., 2014. New taphonomic analysis of large-bodied primate assemblage from Cooper's D, Bloubank Valley, South Africa. South African Archaeological Bulletin. 69, 49-58.

Villa, P., Mahieu, E., 1991. Breakage patterns of human long bones. Journal of Human Evolution. 21, 27-48.

Yellen, J., Brooks, A., Cornelissen, E., Mehlman, M., Stewart, K., 1995. A middle stone age worked bone industry from Katanda, Upper Semliki Valley, Zaire. Science. 268, $553-$ 556.

Zutovski, K., Barkai, R., 2016. The use of elephant bones for making Acheulian handaxes: A fresh look at old bones. Quaternary International. 406, 227-238. 


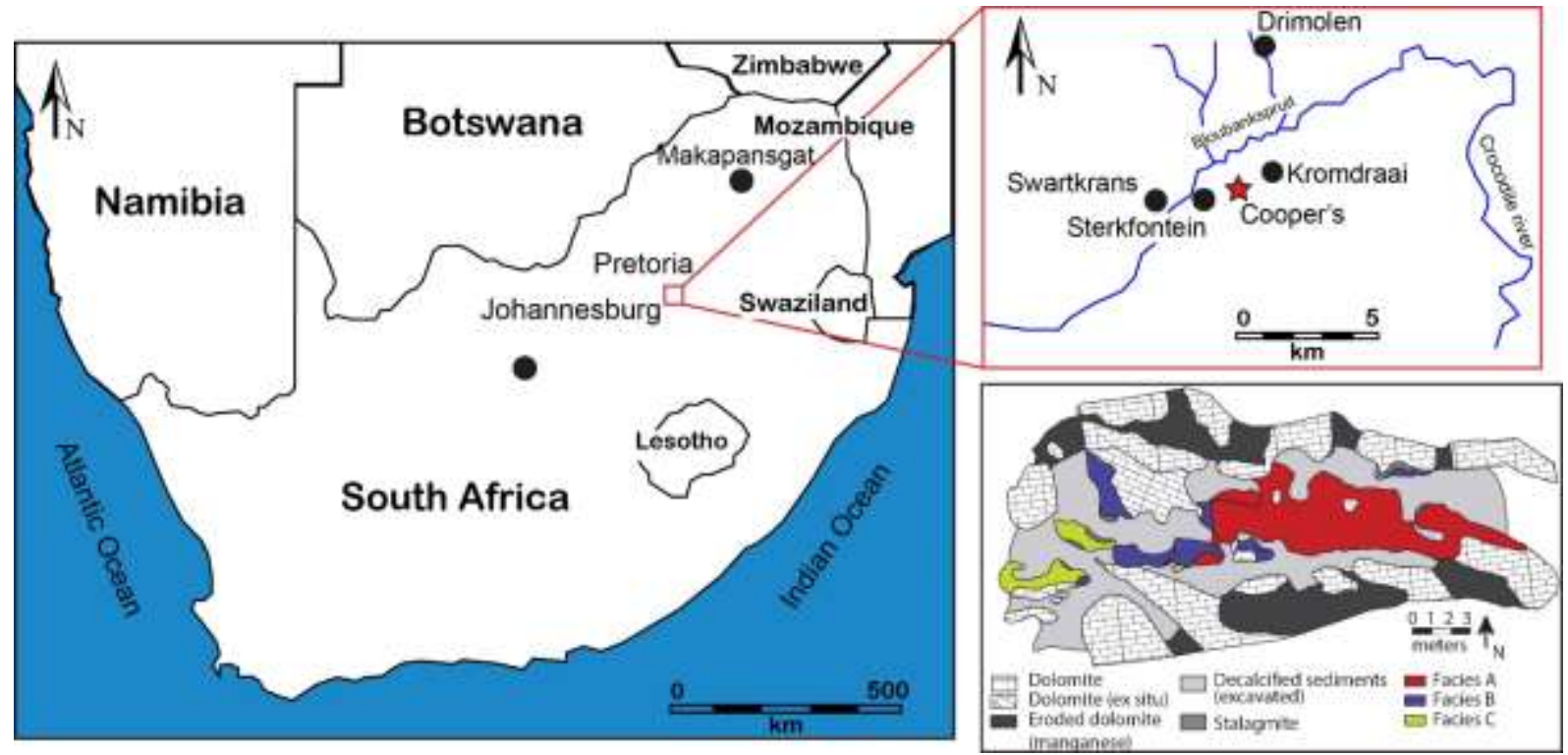

561 Figure 1: Locality of Cooper's Cave and other Early Stone Age-bearing bone tool sites in South 562 Africa with a geological plan of the Cooper's D site (modified after de Ruiter et al., 2009). 


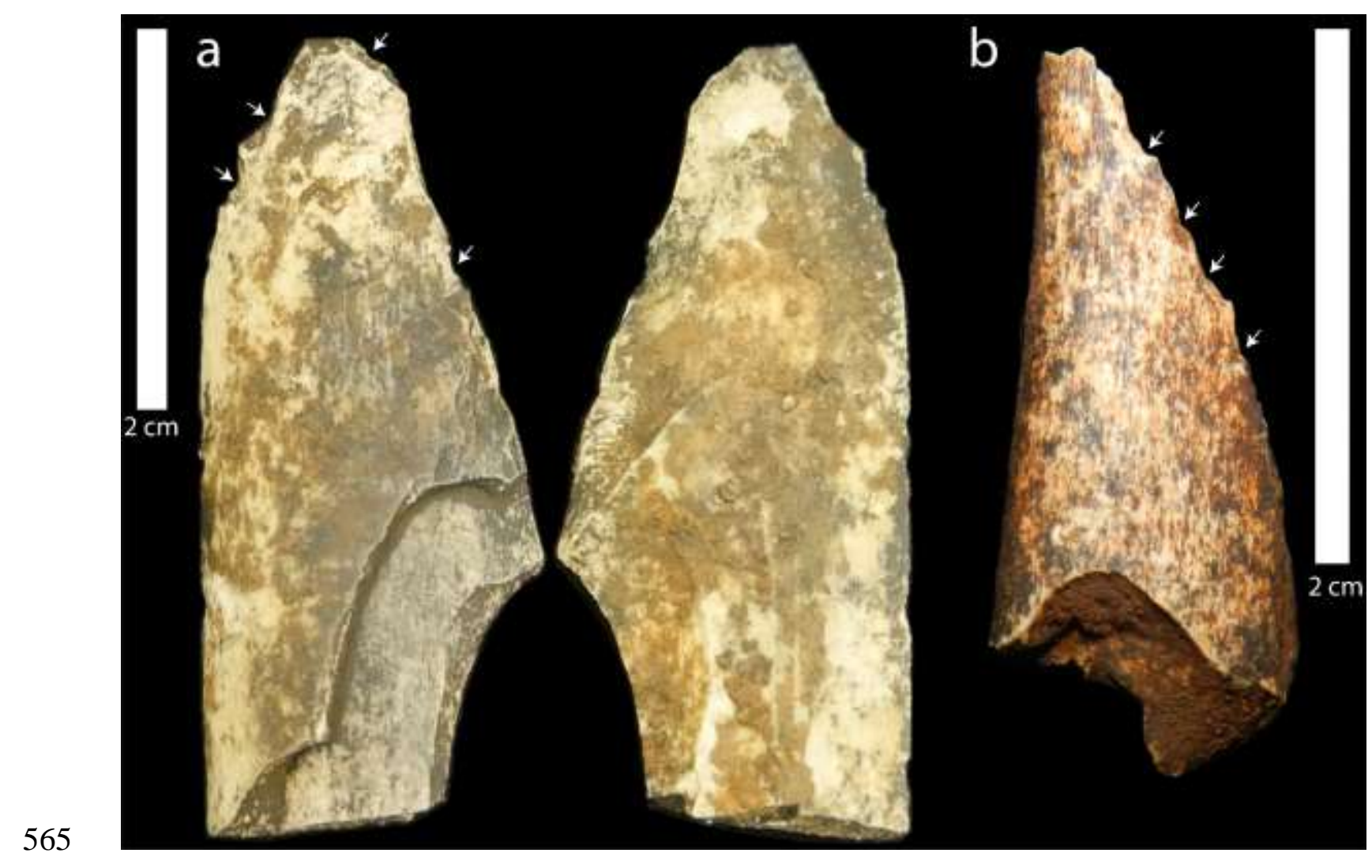

566 Figure 2: Photographs of specimens CD.9977 (a) and CD.3046C (b) displaying denticulated 567 micro flake scars along their edges (arrows). Scales $=2 \mathrm{~cm}$. 


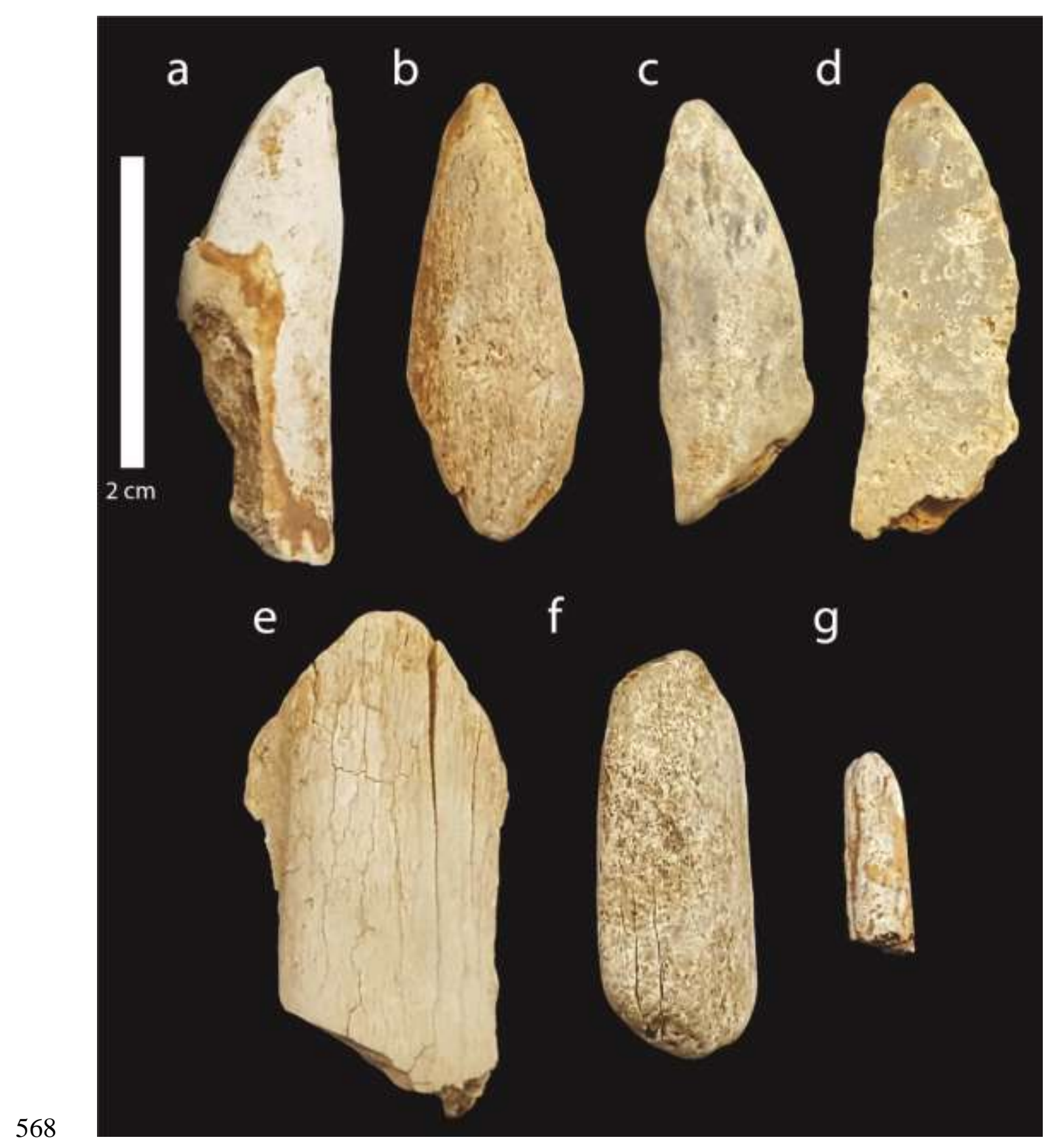

569 Figure 3: Rounded bone fragments from Cooper's D interpreted as pseudo-tools; CD.1649 (a), 570 CD.7900 (b), CD.15631 (c), CD.3538 (d), CD.3529 (e), CD.3528 (f), CD.343 (g). Scale = 2 $571 \mathrm{~cm}$ 


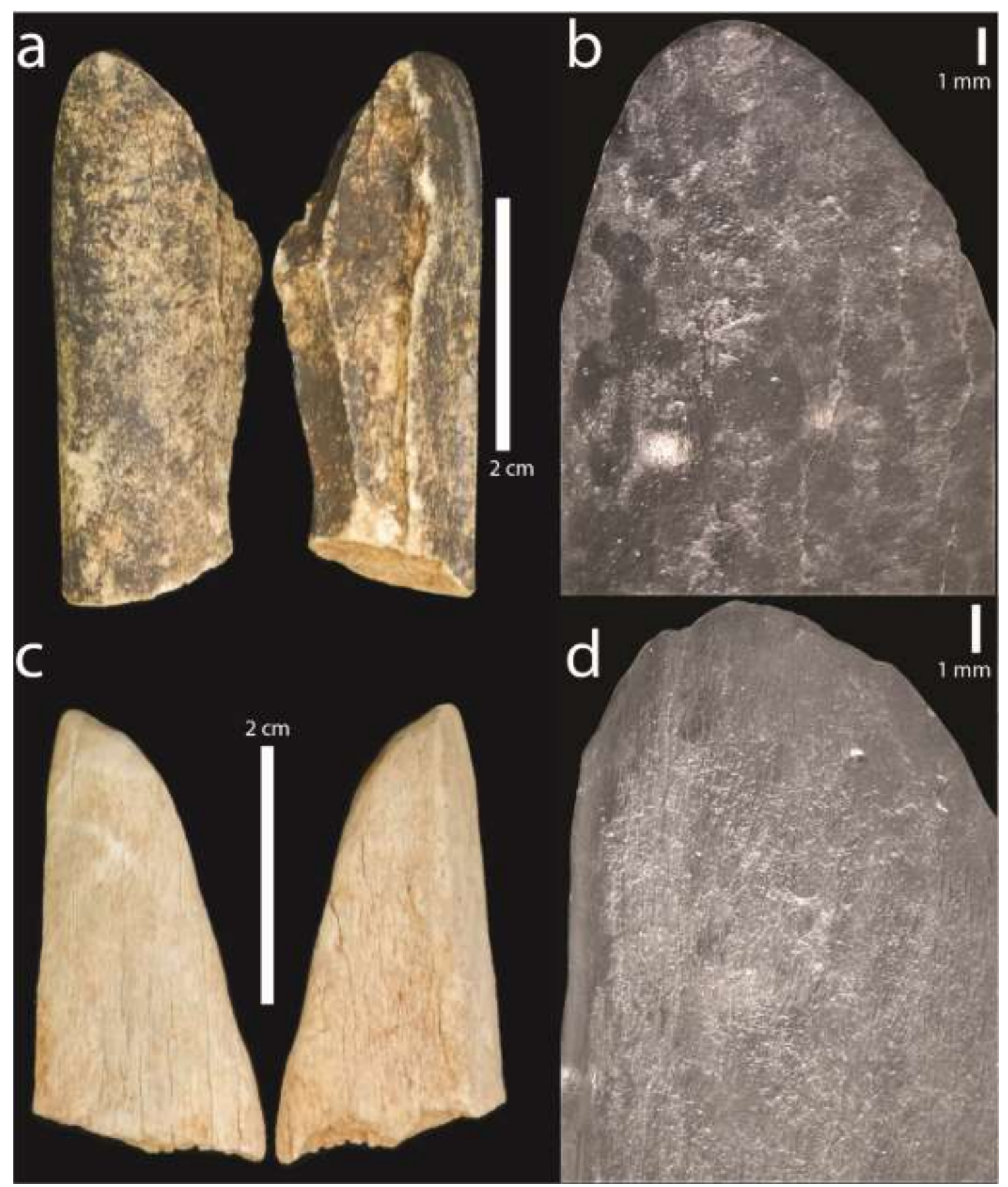

574 Figure 4: Photographs of bone fragments from Cooper's D interpreted as pseudo-tools, 575 CD.6978A (a) and CD.1293 (c) and photographs of their rounded tips taken in transmitted light 576 on resin replicas CD.6978A (b) and CD.1293 (d). Scales $=2 \mathrm{~cm} \mathrm{(a,} \mathrm{c)} \mathrm{and} 1 \mathrm{~mm}(\mathrm{~b}, \mathrm{~d})$. 


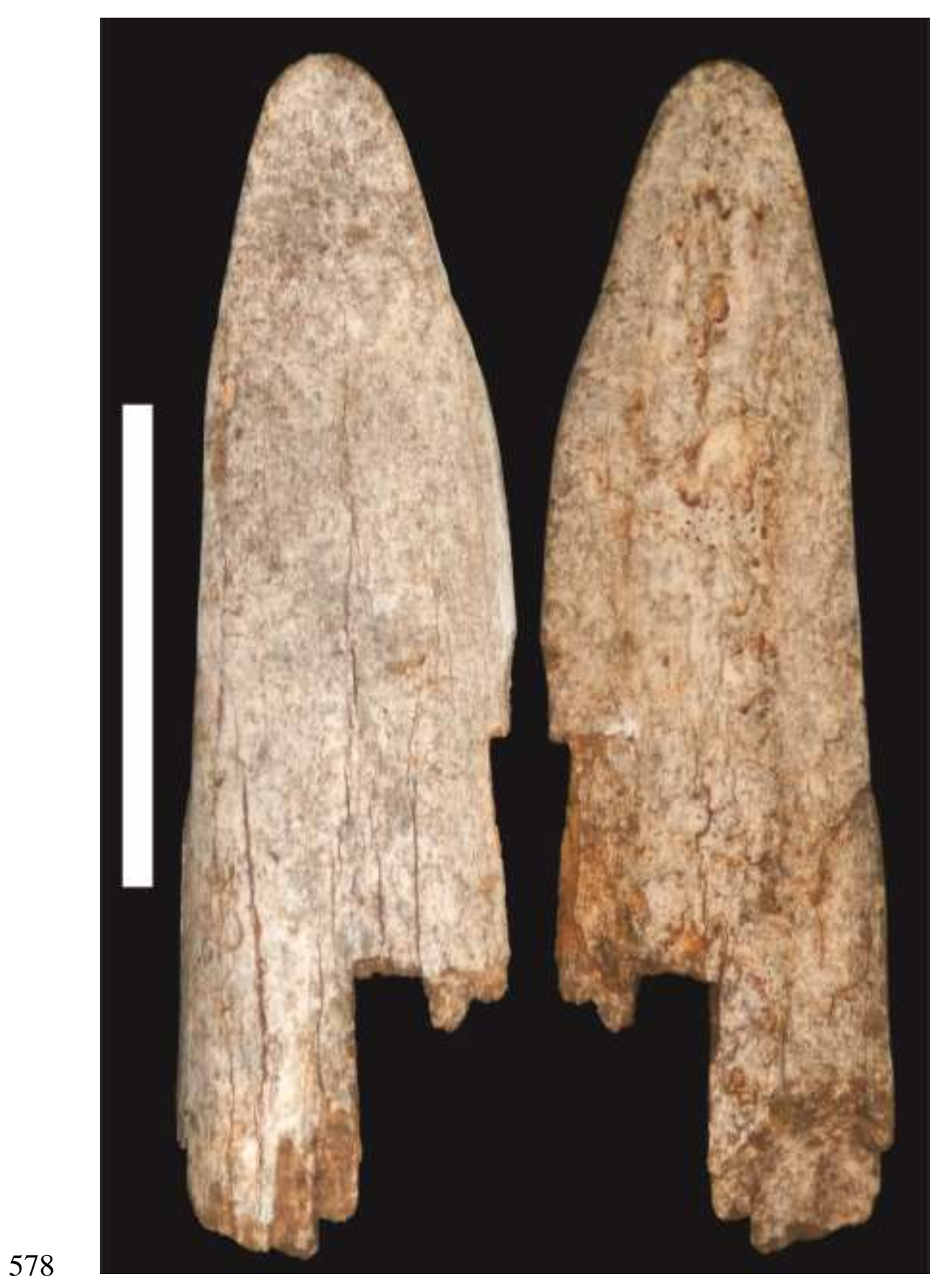

579 Figure 5: Photographs of the bone tool from Cooper's D (CD.7895) showing the cortical (left) 580 and medullary (right) surfaces. Scale $=2 \mathrm{~cm}$. 


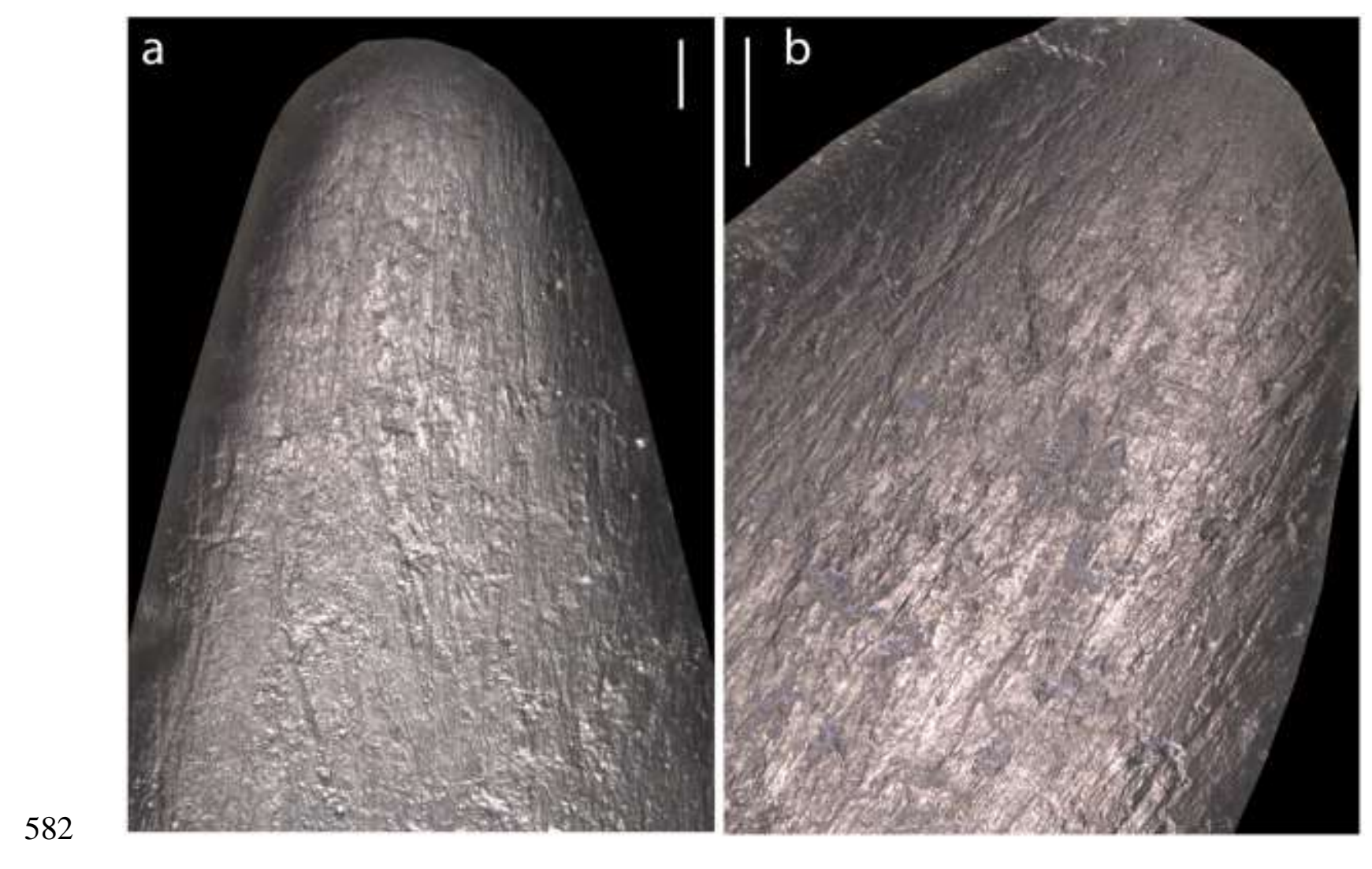

583 Figure 6: Periosteal surface of the bone tool tip from Cooper's D (CD.7895) showing 584 characteristic longitudinal subparallel, intersecting striations. Photographs taken in transmitted 585 light on resin replicas. Scales $=1 \mathrm{~mm}$. 

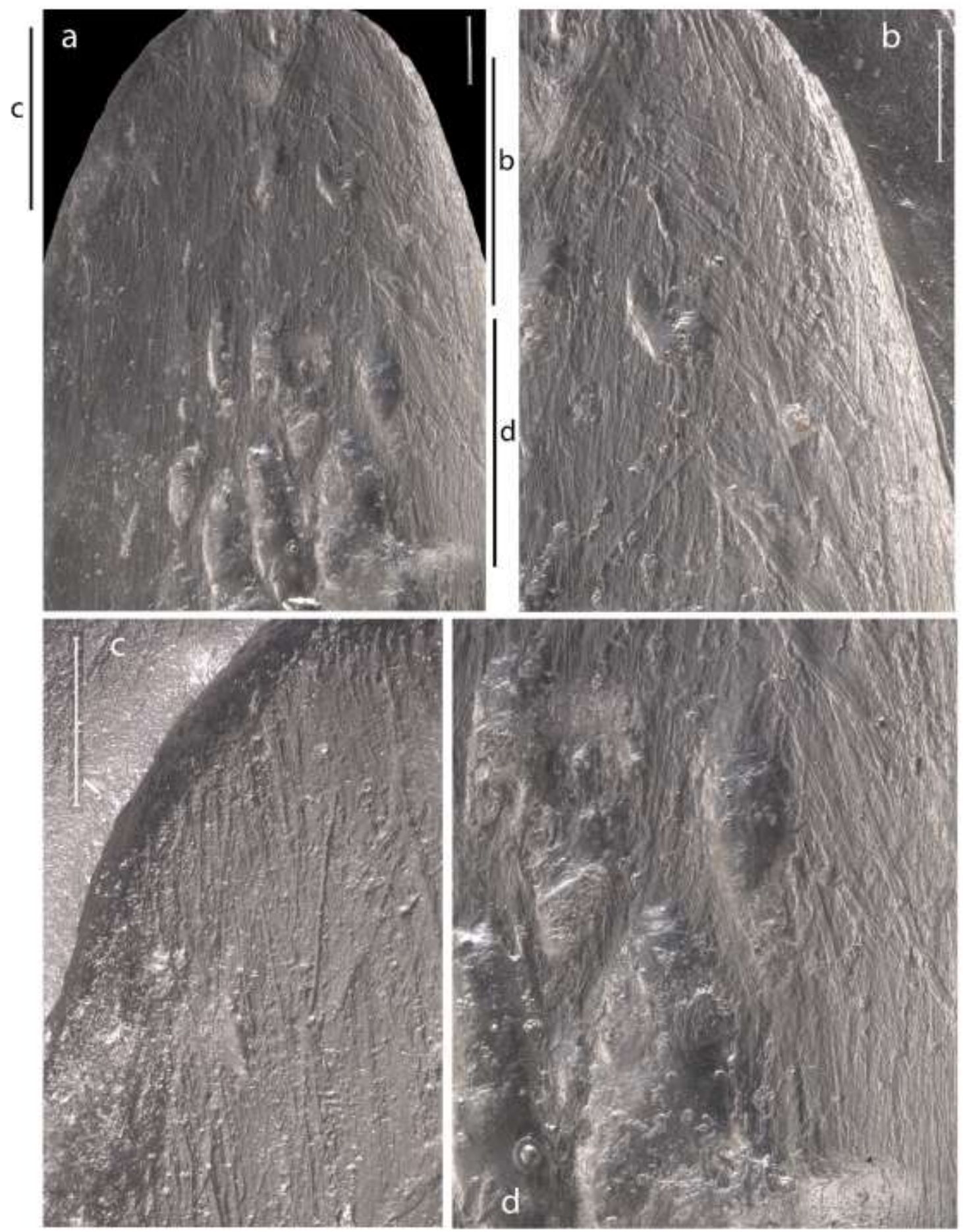

588 Figure 7: Medullary surface (a) of the bone tool from Cooper's D (CD.7895) and close-up

589 views of the tip (b-c) and right side of the object. Notice the myriad number of individual

590 intersecting lines flattening the bone surface and only sparing concave areas of trabecular bone.

591 Scales $=1 \mathrm{~mm}$. 


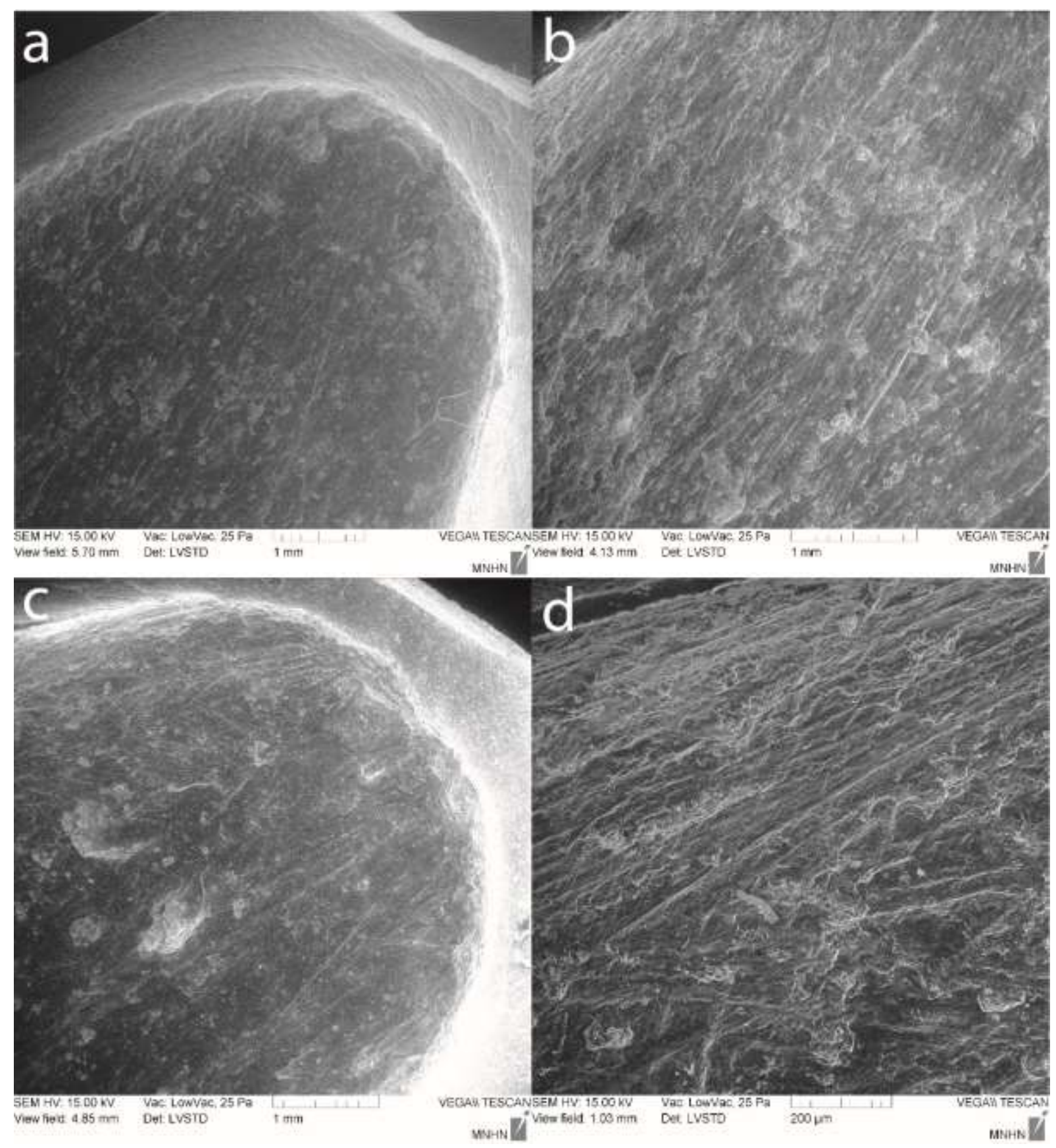

594 Figure 8: Scanning electron micrographs of the Cooper's D bone tool tip (CD.7895) (top and 595 bottom left) and close-up views (right) showing microstriations produced by the use of the tool. 596 Scales $=1 \mathrm{~mm}(\mathrm{a}-\mathrm{c})$ and $200 \mu \mathrm{m}(\mathrm{d})$. 